\title{
Jacaratia corumbensis O. Kuntze a New Vegetable Source for Milk-Clotting Enzymes
}

\author{
Ana Rodrigues Duarte ${ }^{1}$, Débora Maria Rodrigues Duarte ${ }^{1}$, Keila Aparecida Moreira ${ }^{1,2}$, \\ Maria Taciana Holanda Cavalcanti ${ }^{1,4}$, José Luiz de Lima-Filho ${ }^{1,3}$ and Ana Lúcia Figueiredo \\ Porto $^{1,4^{*}}$ \\ ${ }^{1}$ Laboratório de Imunopatologia Keizo Asami; Universidade Federal de Pernambuco; Av. Prof. Moraes Rego, s/n; \\ 50670-901; Recife - PE - Brasil. ${ }^{2}$ Unidade Acadêmica de Garanhuns; Universidade Federal Rural de Pernambuco; \\ Rua Ernesto Dourado, 82; 55296-190; Garanhuns - PE - Brasil. ${ }^{3}$ Departamento de Bioquímica; Universidade \\ Federal de Pernambuco; Av. Prof. Moraes Rego, s/n; 50670-420; Recife - PE - Brasil. ${ }^{4}$ Departamento de \\ Morfologia e Fisiologia Animal; Universidade Federal Rural de Pernambuco; Rua Dom Manoel de Medeiros, s/n; \\ 52171-900; Recife - PE - Brasil
}

\begin{abstract}
The partial characterization and purification of milk clotting enzyme obtained from the (root latex) of Jacaratia corumbensis $O$. kuntze was studied, by fractional precipitation with ammonium sulphate and ion exchange chromatography. The ammonium sulphate precipitate showed five fractions (AS1-0-20\%; AS2 - 20-40\%; AS3 - 4060\%; AS4-60-80\%; AS5 - 80-100\%) and among the fractions obtained, the 40-60\% fraction (AS3) showed the highest milk clotting activity with a purification factor of 1.2 fold in relation to the crude extract. This fraction when applied on Mono $Q$ column yielded two protein peaks ( $p 1$ and $p 2$ ), but $p 1$ pool showed the best milk-clotting activity. The optimal $\mathrm{pH}$ for the crude and partially purified extract was 6.5 and 7.0, respectively. The maximum milk-clotting activity was at $55^{\circ} \mathrm{C}$ for the both crude and partially purified extracts. The enzyme was inhibited by iodoacetic acid which suggested that this enzyme was a cysteine protease, with molecular weight of $33 \mathrm{kDa}$.
\end{abstract}

Key words: Jacaratia corumbensis O. kuntze; Milk clotting enzyme; Characterization; Purification, Vegetable enzyme

\section{INTRODUCTION}

Milk-clotting by proteolytic enzymes is very important in dairy technology. The enzymatic coagulation of milk involves a specific hydrolysis of the Phe-Met bond kappa-casein covering the protein micelles (Law, 1999).

The traditional product, calf rennet, has always been the reference product because high chymosin concentration that cleaves specifically kappacasein, induced milk-clotting with high specific milk-clotting activity and low general proteolytic activity. It's very important for cheese manufacture because minimize the general nonespecific proteolysis and prevents excessive proteolysis during maturation, ensuring the correct ratio between protein and peptides. The excessive

\footnotetext{
*Author for correspondence: ana.porto@pq.cnpq.br
} 
proteolysis can, moreover, lead to bitter taste (Law, 1999).

In the past, only calf rennet was used for cheese making. The worldwide increase of cheese production and the reduced supply of calf rennet led to search for rennet substitutes (Lopes et al., 1998). Rennet substitutes of plant origin have been increasingly used to manufacture the cheese, especially at the artisanal level. Application of plant coagulants allows target cheese production, and hence contributes to improve the nutritional input of those populations on whom restrictions are improbable by the use of animal rennets (Silva and Malcata, 2005).

Vegetable rennet extracted from Cynara cardunculus L. (cardoon flowers) is used for various cheese productions, such as La Serena cheese, a semi-hard Spanish variety manufactured from raw merino ewes' milk. Aqueous extracts of these flowers have been employed for ages in Portugal and bordering regions of Spain for the production of traditional cheeses from raw ewe's milk (Roa et al., 1999) and/or goat's milk (Silva et al., 2003). High levels of proteolytic enzymes in the flowers are responsible for the effective clotting of milk (Lamas et al., 2001).

Plant proteases employed for cheese production in various areas of the world include papain, bromelain, ficin, oryzasin, cucumisin, sodom apple protease and lettuce protease, extracted from Carica papaya, Ananas comosus, Ficus glabra, Oriza sativa, Cucumis melo ssp, Calotropis procera and Lactuca sativa, respectively (Uchikaba and Kaneda, 1996; Asakura et al., 1997; Lo Piero et al., 2002).

Wild papaya (Jacaratia corumbensis $\mathrm{O}$. kuntze) is a shrub occurring in the Brazilian semi-arid region. Its fruits are consumed by wild animals and the tuber is used for animal feed in the drought periods and for making sweet paste by small farmers (Cavalcanti et al., 1999).

In this work, the biochemical properties and partial purification of milk-clotting protease from Jacaratia corumbensis $\mathrm{O}$. kuntze was studied.

\section{MATERIALS AND METHODS}

\section{Enzyme Extraction}

Fresh biological material (Jacaratia corumbensis O. kuntze root) was washed several times with distilled water and disinfected with sodium hypochloride $(10 \% \mathrm{v} / \mathrm{v})$. After this, the latex obtained from the root was diluted $(1 \mathrm{~g})$ in $100 \mathrm{ml}$ $0.9 \%(\mathrm{w} / \mathrm{v}) \mathrm{NaCl}$ solution. The solution was then stirred at room temperature $\left(25^{\circ} \mathrm{C}\right)$ for $1 \mathrm{~h}$ and filtered through a filter paper and maintained at $4^{\circ} \mathrm{C}$. This solution was used for the determination of total protein, proteolytic and milk clotting activities.

\section{Protease Assay}

Total protease activity was assayed at $25^{\circ} \mathrm{C}$ as described by Ginther (1979), using azocasein (1\% $\mathrm{w} / \mathrm{v}$, Sigma) in $0.1 \mathrm{M}$ Tris- $\mathrm{HCl}$ ( $\mathrm{pH}$ 7.6) containing $10 \mathrm{mM} \mathrm{CaCl} 2$ as a substrate. One unit of activity was defined as the amount of enzyme that produces an increase in the absorbance of 1.0 in $1 \mathrm{~h}$ at $440 \mathrm{~nm}$. Total protein was determined by the method described by Bradford (1976) using bovine serum albumin as standard.

\section{Milk Clotting Protease Assay}

The milk-clotting protease was assayed as described by Arima et al. (1970). A $10 \%$ (w/v) skim milk solution containing $10 \mathrm{mM} \mathrm{CaCl}_{2}$ was used as substrate. One unit of activity was defined as the amount of enzyme that clotted $1 \mathrm{ml}$ of substrate in $40 \mathrm{~min}$ at $35^{\circ} \mathrm{C}$.

\section{Partial Purification of Milk Clotting Protease}

For the initial purification step, the crude extract containing the enzyme was fractionated using the increasing concentrations of ammonium sulphate as described by Green and Hughens (1955). Fractions named AS1, AS2, AS3, AS4 and AS5 were precipitated with $0-20,20-40,40-60,60-80$ and $80-100 \%$ ammonium sulphate, respectively at $4^{\circ} \mathrm{C}$. The solution obtained was dissolved, were centrifugation $\left(20,200 \mathrm{xg}\right.$ for $15 \mathrm{~min}$ at $\left.4^{\circ} \mathrm{C}\right)$, the precipitates collected were dissolved in $2 \mathrm{ml}$ of 0.1 $\mathrm{M}$ phosphate buffer $\mathrm{pH}$ 6.5. The enzyme solution obtain was dialyzed against the same buffer for 24 $\mathrm{h}$, at $4^{\circ} \mathrm{C}$. The proteolytic and milk-clotting activities were determined as described previously. The enzyme solution precipitated in $40-60 \%$ ammonium sulfate was used as sample for chromatography in Akta system (Pharmacia).

The Mono Q HR 10/10 column (Pharmacia) was equilibrated with $0.1 \mathrm{M}$ phosphate buffer, $\mathrm{pH} 6.5$ as described by the manufacturer. For the elution two buffers were used: Solution A $(0.1 \mathrm{M}$ phosphate buffer $\mathrm{pH}$ 6.5) and solution $\mathrm{B}$ (1 M $\mathrm{NaCl}$ ) at a flow rate of $1.5 \mathrm{~mL} / \mathrm{min}$ under linear gradient from 0 to $200 \mathrm{mM}$ buffer B. The protein peaks were detected by the absorbance at $280 \mathrm{~nm}$ 
and fractions were collected at the outlet stream. The proteolytic and milk-clotting activities of each protein fraction were determined as described previously.

\section{Effects of pH on Protease Activity and Stability}

Protease activity was measured at different $\mathrm{pH}$ values using azoalbumin as substrate. The azoalbumin solution was prepared in range $\mathrm{pH} 3.5$ -8.5 in various buffer at $25^{\circ} \mathrm{C}$, such as: $100 \mathrm{mM}$ citrate-phosphate buffer (pH $3.5-5.8), 100 \mathrm{mM}$ phosphate buffer ( $\mathrm{pH} 5.8$ - 7.5), and $100 \mathrm{mM}$ Tris- $\mathrm{HCl}$ buffer ( $\mathrm{pH} 7.0-8.5)$. The $\mathrm{pH}$ stability was determined by incubation at different $\mathrm{pH}$ values $(\mathrm{pH} 3.5-8.5)$ as described above, with incubation time varying from 30 to 120 minutes. After this time, the protease activity was measured at $25^{\circ} \mathrm{C}$, using azocasein as substrate in $100 \mathrm{mM}$ Tris-HCl buffer, $\mathrm{pH}$ 7.6, as described previously.

\section{Effect of Temperature on Protease Activity and Stability}

The optimum temperature for milk-clotting activity was assayed at various temperatures $\left(35^{\circ}\right.$ $85^{\circ} \mathrm{C}$ ), using skim milk $10 \%$ as substrate.

The enzyme solution was pre-incubated over range of temperature from $35^{\circ}$ to $85^{\circ} \mathrm{C}$, with incubation time varied from 30 to 120 minutes for determination of thermal stability. In this experiment, $10 \%$ skim milk was used as substrate.

\section{Inhibition Studies}

To determine the class and specificity of the protease, enzyme extracts were incubated for $1 \mathrm{~h}$ at $37^{\circ} \mathrm{C}$ with the inhibitors and then added to azocasein as described previously. The inhibitors used were: $0.1 \mathrm{mM}$ phenylmethylsulphonylfluoride (PMSF), $\quad 0.1 \mathrm{mM}$ pepstatin $\mathrm{A}, \quad 0.1 \mathrm{mM}$ benzamidine solution in dimethyl sulfoxide (DMSO), $0.1 \mathrm{mM}$ ethylenediamine tetraacetic (EDTA) and $0.1 \mathrm{mM}$ iodoacetic acid.

\section{Electrophoresis}

Polyacrylamide gel electrophoresis (SDS-PAGE) (Laemmli, 1970) was carried out 5\% (w/v) stacking gel and $12.5 \%(\mathrm{w} / \mathrm{v})$ separating gel. The molecular weight of the milk clotting protease from Jacaratia corumbensis O. kuntze was estimated using the protein standards (Sigma): bovine albumin $(66.0 \mathrm{kDa})$, ovalbumin $(45.0 \mathrm{kDa})$, glyceraldehyde 3-phosphate dehydrogenase (36.0 $\mathrm{kDa})$, carbonic anhydrase (29.0 kDa), trypsinogen
(24.0 kDa), trypsin inhibitor soybean $(20.1 \mathrm{kDa})$ and lactalbumin $(14.2 \mathrm{kDa})$.

\section{RESULTS AND DISCUSSION}

\section{Protease Purification}

Various purification protocol for milk-clotting protease the vegetable have been described, mostly using chromatography. The aim of this work was to achieve one single and effective protocol, using ammonium sulphate precipitation as pre-purification and ion exchange chromatography. Salting out (ammonium sulphate precipitation) of proteins is a widely used technique in enzyme purification, which takes advantages of the desolvation effect caused by high concentrations of salts. This phenomenon is appropriate not so much for the fractionations of proteins, but mainly is their concentration, and is also useful for the removal of some contaminants (Barros et al., 2001). In this case, the ammonium sulphate precipitation of crude extract showed that protease fractionated at 40 to $60 \%$ saturation, give a $165.5 \mathrm{U} / \mathrm{mg}$ milk-clotting activity, was the best. The yield in terms of protein content was $40 \%$, the recovery in activity of $50 \%$ and a purification factor of 1.2 was achieved, in relation to the crude extract. The results were similar to those found for serine protease from lettuce leaves (Lactuca sativa L.), which showed that proteolytic activity was recovered in the 55\% ammonium sulphate saturation fraction (Lo Piero and Petrone, 1999). A partial purification of the proteolytic enzyme from fig tree latex was carried out between 50 to 85\% saturation (Oner and Akar, 1993). The study of proteases from Cynara cardunculus showed three proteases with milk clotting activity after fractional ammonium sulphate precipitation between 30 and $80 \%$ saturation (Heimgartner et al., 1990). Ammonium sulphate precipitation was chosen in this study because of its simplicity and the economy of the method, but results showed that there was no significant increase in the milk clotting activity. The AS3 fraction (40-60\% ammonim sulfate) with milk-clotting activity was applied to a Mono Q HR 10/10 column. Two protein peaks ( $\mathrm{p} 1$ and $\mathrm{p} 2$ ) were obtained, and only in the first milk-clotting activity was observed. The elution pattern of the chromatography is shown in Fig. 1. After this chromatography, the purified enzyme solution obtained was used as sample for electrophoresis (SDS-PAGE). In Fig. 2 
can be observed the SDS-PAGE gel, with one single major band, which revealed a protein with a molecular weight of approximately $33 \mathrm{kDa}$.

These results can be compared with study of milk clotting protease from flowers of Cynara cardunculus with three proteases with milk clotting activity after two steps of the chromatography (DEAE-Sepharose and MonoQ column) (Heimgartner et al., 1990). The purified proteases showed only one band for each protease, with molecular weights of 41,42 and $45 \mathrm{kDa}$. Other work showed the presence of three peaks corresponding to Cardosin A and Cardosin B after ion exchange chromatography that purified the acidic dried flowers extract of $C$. cardunculus with gel filtration (Sephacryl S-100 - Pharmacia) and ion exchange chromatography (HiTrap Q HP - Pharmacia) (Silva et al., 2003). The electrophoretogram profile of three peaks showed polypeptides with 30 to $15 \mathrm{kDa}$ for cardosin A and $31 \mathrm{kDa}$ to $14 \mathrm{kDa}$ for cardosin $\mathrm{B}$. The purification of milk clotting protease from lettuce leaves by combination of $\left(\mathrm{NH}_{4}\right) \mathrm{SO}_{4}$ fractionation, gel filtration and anionic exchange chromatography gave a single band with an apparent molecular weight of $40 \mathrm{kDa}$ (Lo Piero et al., 2002).

Results indicated that the purification of milkclotting enzyme from $J$. corumbensis could be achieved in two steps, one pre-purification by ammonium sulfate precipitation and chromatography by using Mono Q HR 10/10 column in Akta system.

\section{Effects of Various Inhibitors}

The specific hydrolysis reaction of kappa-casein protein in milk can be evaluated by the protease type. The main method for the study of protease types is reaction in the presence of inhibitors. The milk clotting protease from $J$. Corumbensis $\mathrm{O}$. kuntze was inhibited completely by iodoacetic acid but was not affected by other inhibitors, suggesting a cysteine protease (table 1). The milkclotting protease reported in literature are aspartic proteases, mainly animal and microbial source, but protease from the vegetable can be used too, such as seric proteases such as cucumisin (EC 3.4.21.25), cysteine proteases i.e. papain (EC 3.4.22.2) and ficin (EC 3.4.22.3) (Uchikaba and Kaneda, 1996).

\section{Effect of pH on Proteolytic Activity/Stability}

The $\mathrm{pH}$-activity profiles of the enzyme from the crude and purified extract are shown in Fig. 3. The activity of the enzyme was optimal when the assay was carried out at $\mathrm{pH} 6.5$ for the crude extract and $\mathrm{pH} 7.0$ for partially purified extract. At $\mathrm{pH} 3.5$, about $35 \%$ and $40 \%$ of the maximum activity was obtained for the crude and partially purified, respectively. At $\mathrm{pH} 8.5$, the protease activity decreased 30 and $60 \%$, respectively for the crude and partially purified extract.

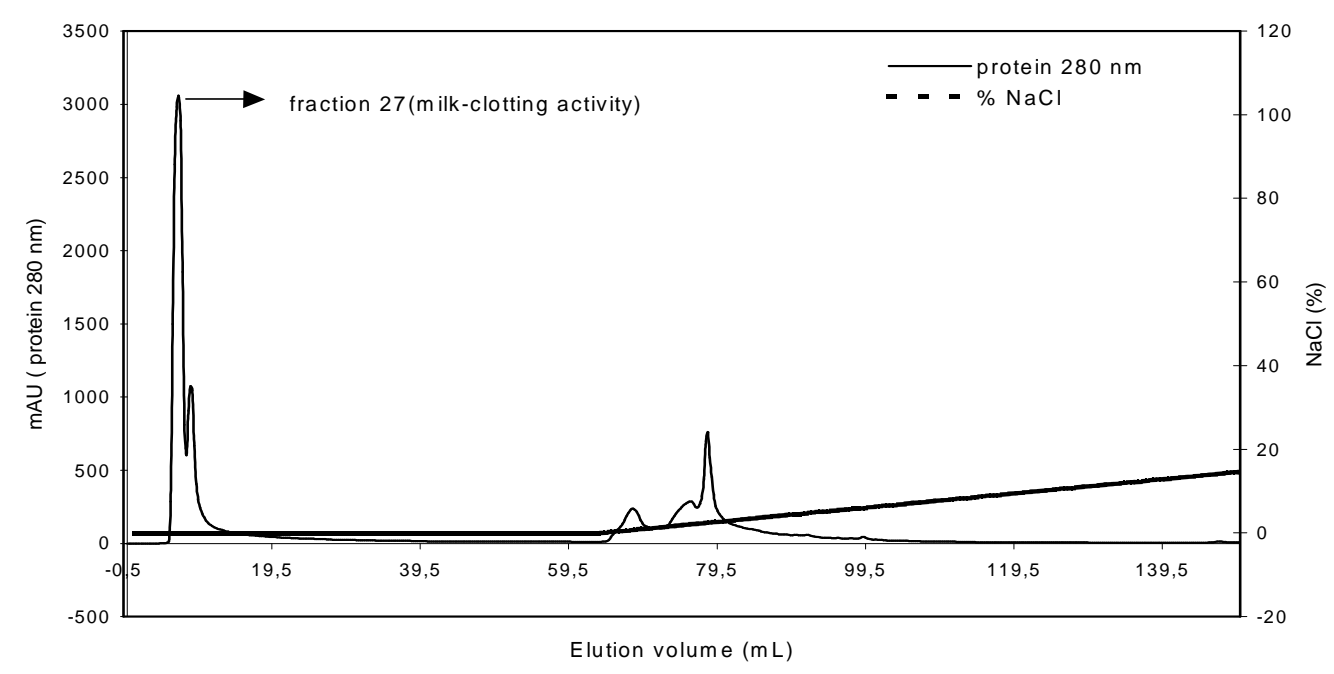

Figure 1 - Elution pattern of the 40-60\%, ammonium sulphate fraction from Jacaratia corumbensis O. kuntze on Mono Q column. 


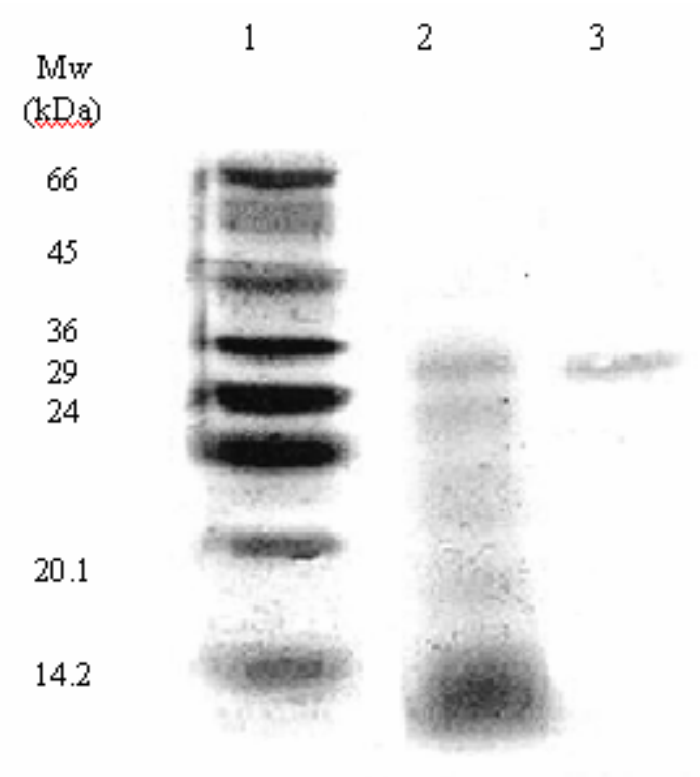

Figure 2 - SDS-PAGE (12.5\%) analysis of the purification procedures of the milk-clotting protease from Jacaratia corumbensis O. kuntze. Lane 1: molecular mass markers; lane 2: ammonium sulphate precipitated fraction 40-60\%, $15 \mu \mathrm{g}$; lane 3. fraction 27 (protein peak first) from the step on Mono Q, $15 \mu \mathrm{g}$.

Table 1 - Effects of various inhibitors on the milk-clotting protease activity from Jacaratia root latex.

\begin{tabular}{ccc}
\hline Inhibitors & $\mathrm{CE}^{\mathrm{a}}$ & Inhibition (\%) \\
\hline EDTA & $9 \pm 1.41$ & $\mathrm{PPE}^{\mathrm{b}}$ \\
PMSF & $20 \pm 0.71$ & $1 \pm 0.0$ \\
Iodoacetic acid & $100 \pm 0.0$ & $11 \pm 2.12$ \\
Pepstatin & $21 \pm 0.0$ & $100 \pm 0.0$ \\
Benzamidine & $11 \pm 1.41$ & $20 \pm 2.12$ \\
\hline
\end{tabular}

${ }^{\mathrm{a}}$ crude extract; ${ }^{\mathrm{b} P E}$ Partially purified protease

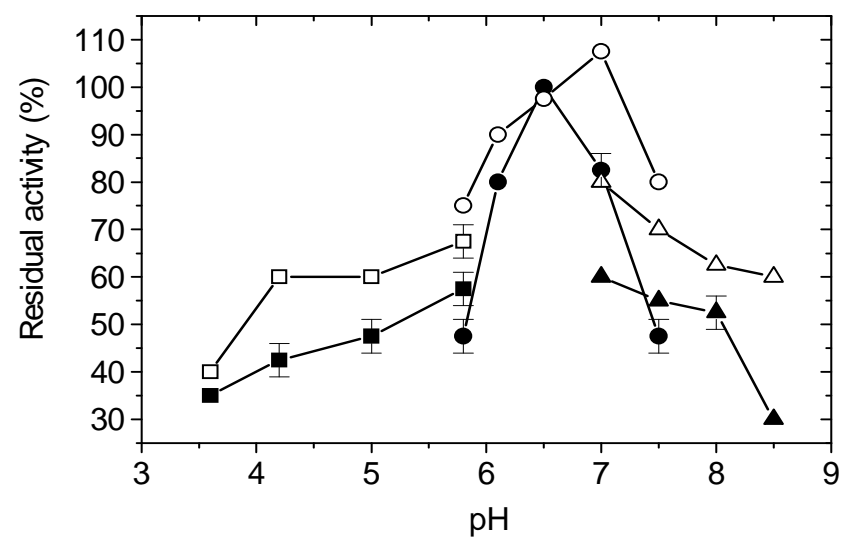

Figure 3 - Effect of $\mathrm{pH}$ on activity the milk-clotting protease of the Jacaratia corumbensis $\mathrm{O}$. kuntze (Crude Extract)-Buffer solutions 0.1M phosphate citrate $(\bullet)$; phosphate $(\bullet)$ and Tris-HCl $(\boldsymbol{\Delta})$, (Partially Purified Extract)-Buffer solutions $0.1 \mathrm{M}$ phosphate citrate $(\square)$; phosphate $(\mathrm{O})$ and Tris- $\mathrm{HCl}(\triangle)$. 
These $\mathrm{pH}$ profile results could be compared with other work for another milk clotting enzyme from Lactuca sativa leaves, where the optimum $\mathrm{pH}$ was around $6.5-8.0$ for several substrates used (Lo Piero et al., 2002). However, the results obtained were different with the milk-clotting enzyme from Cynara cardunculus, which showed a maximum activity around $\mathrm{pH}$ 5.1. Milk-clotting protease obtained from the latex by Ficus carica had maximum activity in the acidic $\mathrm{pH}$ range (Fadyloglu, 2001).

The crude and partially purified extracts were stable in the acidic $\mathrm{pH}$ range $(3.6-6.5)$ and retained $100 \%$ of initial proteolytic activity after 120 min (as shown the Fig. 4). In the basic $\mathrm{pH}$ range, however, only 60 and $80 \%$ (crude and partial purified) of initial proteolytic activity was retained after $120 \mathrm{~min}$ in $\mathrm{pH} 8.5$.

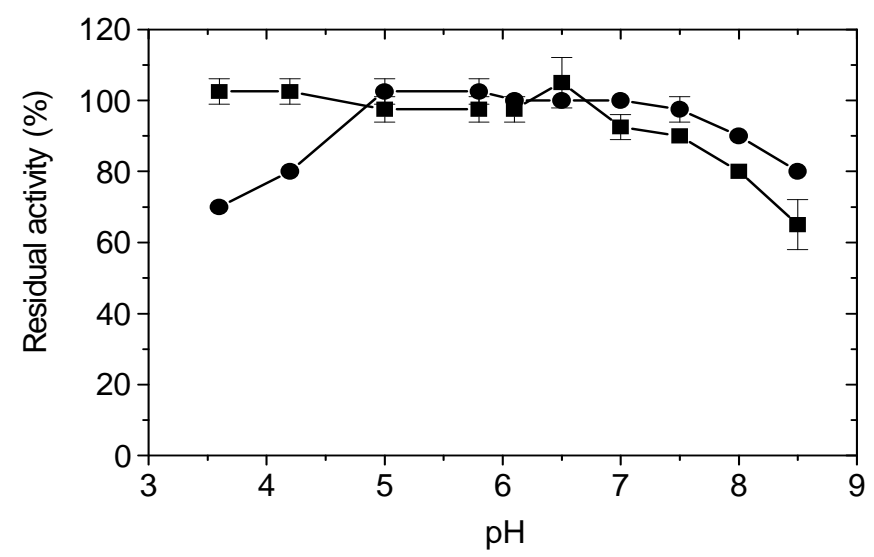

Figure 4 - Effect of pH on stability of crude $(\bullet)$ and partially purified $(\bullet)$ protease from Jacaratia corumbensis $\mathrm{O}$. kuntze carried out at $25^{\circ} \mathrm{C}$ during $120 \mathrm{~min}$. The reaction was carried out in the following buffer solutions $0.1 \mathrm{M}$ : phosphate-citrate $(3.6-5.8)$, phosphate $(6.1$ - 7.5) and Tris- $\mathrm{HCl}(8.0$ and 8.5).

\section{Effect of Temperature on Milk-clotting Activity/Stability}

The optimal temperature for milk-clotting activity was at $55^{\circ} \mathrm{C}$ for both crude and partially purified extract, showing $800 \%$ and $270 \%$ of activity (Fig. 5), but their activities were decreased at 75 and $85^{\circ} \mathrm{C}$ for both the extracts. The results were similar to those found by Lo Piero et al. (2002) and Asakura et al. (1997) with the proteases from Lactuca sativa L. and oryzasin from Oriza sativa that exhibited optimal temperature as $50^{\circ} \mathrm{C}$. The crude and partially purified extract of $J$. corumbensis retained approximately $100 \%$ milkclotting activity after 15 and $30 \mathrm{~min}$ at $35^{\circ} \mathrm{C}$, respectively (Figs. 6 and 7).

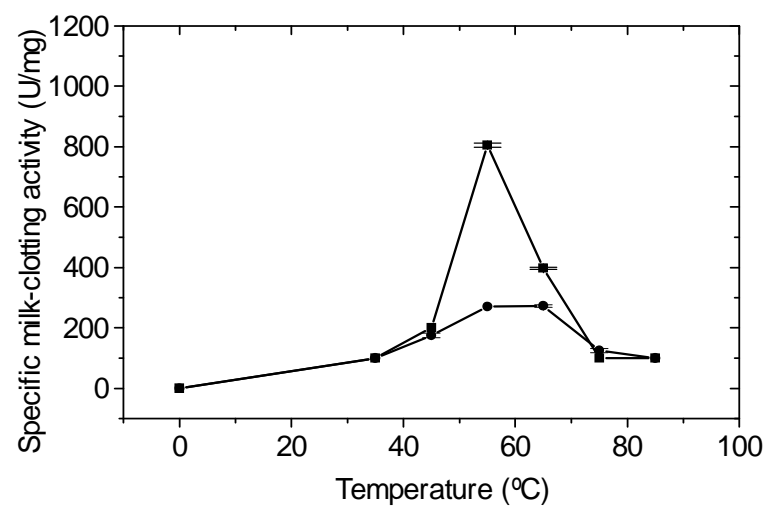

Figure 5 - Effect of temperature on the milk-clotting protease of the Jacaratia corumbensis O. kuntze Crude Extract (•); Partially Purified Extract $(\bullet)$. 


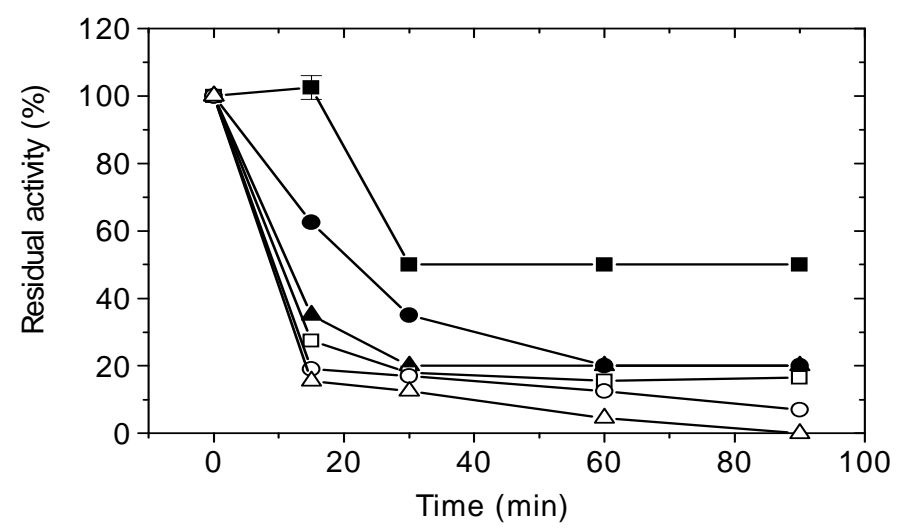

Figure 6 - Thermal stability of proteases from Jacaratia corumbensis O. kuntze (Crude Extract) $35^{\circ}(\bullet) ; 45^{\circ}(\bullet) ; 55^{\circ}(\Delta) ; 65^{\circ}(\square) ; 75^{\circ}(\triangle)$ and $85^{\circ} \mathrm{C}(\bigcirc)$.

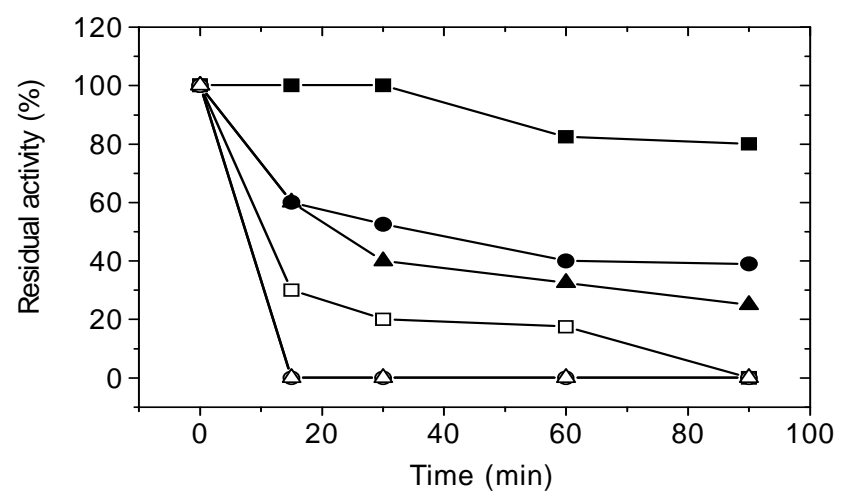

Figure 7 - Thermal stability of proteases from Jacaratia corumbensis O. kuntze (Partially Purified Extract) $35^{\circ}(\bullet) ; 45^{\circ}(\bullet) ; 55^{\circ}(\Delta) ; 65^{\circ}(\square) ; 75^{\circ}(\triangle)$ and $85^{\circ} \mathrm{C}(\mathrm{O})$.

However, the activity of crude extract fell to $13 \%$ after $15 \mathrm{~min}$ at $85^{\circ} \mathrm{C}$ was inactivated after $90 \mathrm{~min}$ at $75^{\circ} \mathrm{C}$. The partially purified extract was inactivated after $15 \mathrm{~min}$ at 75 and $85^{\circ} \mathrm{C}$. These results could be compared with other work which did not observe a loss of milk-clotting activity with a crude extract obtained by Solanum dobium after $10 \mathrm{~min}$ at 40 and $50^{\circ} \mathrm{C}$ (Yousief et al., 1996). However, the results reported for lettuce protease leaves showed that incubation at $50^{\circ} \mathrm{C}$ did not greatly affect the enzyme, as it retained $80 \%$ of original activity (Lo Piero et al., 2002). The partially purified extract retained approximately $80 \%$ milk-clotting activity after $90 \mathrm{~min}$ at $35^{\circ} \mathrm{C}$, but activity decrease to $20 \%$ after $90 \mathrm{~min}$ at $55^{\circ} \mathrm{C}$. The partially purified extract was inactivated at $65^{\circ} \mathrm{C}$ after $15 \mathrm{~min}$.

The results suggested that the proteases obtained from the latex of Jacaratia corumbensis $\mathrm{O}$. kuntze root might be a potential source for enzymes useful in dairy applications. 


\section{ACKNOWLEDGEMENTS}

The authors are thankful to Federal University of Pernambuco, Rural Federal University of Pernambuco, University Foundation Vale do Acaraú, FACEPE and CNPq for financial support.

\section{RESUMO}

A enzima coagulante de leite obtida de látex de raiz de Jacaratia corumbensis O. kuntze foi caracterizada parcialmente e purificada, por precipitação fracionária com sulfato de amônio e cromatografia de troca de íon. Foram utilizadas cinco frações de sulfato de amônio (AS1 - 0-20\%; AS2 - 20-40\%; AS3 - 40-60\%; AS4 - 60-80\%; AS5 - 80-100\%), a fração 40-60\% (AS3) mostrou alta atividade coagulante com um fator de purificação de 1,2 vezes em relação ao extrato bruto. Esta fração foi aplicada em coluna Mono Q obtendo dois picos de proteína (p1 e p2), o p1 mostrou melhor atividade coagulante. $\mathrm{O} \mathrm{pH}$ ótimo para o extrato bruto e parcialmente purificado foi 6,5 e 7,0 , respectivamente. A atividade coagulante foi atingida a $55^{\circ} \mathrm{C}$ para ambos os extratos, bruto e parcialmente purificado. A enzima foi inibida por ácido iodoacético que sugere que esta enzima é uma cisteína protease, com peso molecular de 33

$\mathrm{kDa}$.

\section{REFERENCES}

Arima, K.; Yu , J. and Iwasaki, S. (1970) Milk-clotting enzyme from Mucor pusillus var. Lindt. Methods in Enzymology, 19, 446-459.

Asakura, T.; Watanabe, H.; Abe, K. and Arai, S. (1997), Oryzasin as an aspartic proteinase occurring in rice seeds: purification, characterization and application to milk clotting. Journal of Agricultural and Food Chemistry, 45, 1070-1075.

Barros, R. M.; Ferreira, C. A.; Silva, S. V. and Malcata, F. X. (2001), Quantitative studies on the enzymatic hydrolysis of milk proteins brought about by cardosins precipitated by ammonium sulfate. Enzyme and Microbiology and Technology, 29, 541-547.

Bradford, M. M. (1976), A rapid and sensitive method for the quantitation of microgram quantities of protein utilizing the principle of protein-dye binding. Analytical Biochemistry, 72, 248-254.
Cavalcanti, N. B.; Lima, J. L. S.; Resende, G. M. and Brito, L. T. L. (1999), Estudo do Xilopódio do mamãozinho-de-veado (Jacaratia corumbensis O. kuntze) no semi-árido do Nordeste. $50^{\circ}$ Congresso Nacional de Botânica. Blumenau, Brasil.

Fadyloglu, S. (2001) Immobilization and characterization of ficin. Nahrung, 45, 143-146.

Ginther, C. L. (1979) Sporulation and the production of serine protease and cephamycin c by Streptomyces lactamdurans. Antimicrobial Agents and Chemotherapy. 522-526.

Green, A. A. and Hughens, W. L. (1955) Protein fractionation on the basis of solubility in aqueous solutions of salts and organic solvents. Methods in Enzymology, 1, 67-90.

Heimgartner, U.; Pietrzak, M., R.; Geertsen, P.; Brodelius, A. C.; Silva-Figueiredo and M. S. S. Pais (1990), Purification and partial characterization of milk clotting proteases from flowers of Cynara cardunculus. Phytochemistry, 29, 1405-1410.

Laemmli, U. K. (1970) Cleavage of structural proteins during the assembly of head of bacteriophage T4. Nature; 227, 680-685.

Lamas E. M.; Barros, R. M.; Balcão, V. M. and Malcata F. X. (2001), Hydrolysis of whey proteins by proteases extracted from Cynara cardunculus and immobilized onto highly activated supports. Enzyme Microbial and Technology, 28, 642-652.

Law, B. A. (1999), Technology of cheesemaking, B. A. Law ed. Sheffield Academic Press, Sheffield., pp. 322.

Lopes, A.; Teixeira, G.; Liberato, M. C.; Pais, M. S. and Clemente A. (1998), New vegetal sources for milk clotting enzymes. Journal of Molecular Catalysis B: Enzyme, 5, 63-68.

Lo Piero, A. R.; Puglisi, I. and Petrone, G. (2002), Characterization of "lettucine", a serine-like protease from Lactuca sativa leaves, as a novel enzyme for milk clotting. Journal of Agricultural and Food Chemical, 50, 2439-2443.

Lo Piero, A. R. and Petrone, G. (1999) Purification and partial characterization of an ATP-hydrolyzing serine protease from lettuce leaves. Phytochemistry, 51, 349-356.

Oner, M. D. and B. Akar, (1993) Separation of the proteolytic enzymes from fig tree latex and its utilization in gaziantep cheese production. Lebensmittel-Wissenschaft uns - Technologie. 26318 321.

Roa, I.; López, M. B. and Mendiola, F. J. (1999), Residual clotting activity and ripening properties of vegetable rennet from Cynara cardunculus in La Serena cheese. Food Research International, 32, 413-419. 
Silva, S. V. and Malcata F. X. (2005), Studies pertaining to coagulant and proteolytic activities of plant proteases from Cynara cardunculus. Food Chemistry, 89 9-26.

Silva, S. V.; Allmere T., Malcata, F. X. and Andrén A. (2003), Comparatives studies on the gelling properties of cardosins extracted from Cynara cardunculus and chimosin on cow's skim milk. International Dairy Journal, 13, 559-564.
Uchikoba, T. and Kaneda, M. (1996), Milk-clotting activity of cucumisin, a plant serine protease from melon fruit. Applied Biochemistry and. Biotechnology, 56, 325-330.

Yousif, B. H.; Mcmahon, D.J. and Shammet, K.M. (1996), Milk-clotting enzyme from Solanum dobium plant. International Dairy Journal, 6, 637-644.

Received: September 21, 2006; Revised: December 28, 2007; Accepted: July 20, 2008. 